Історико-політичні проблеми сучасного світу: Збірник наукових статей. - Чернівці: Чернівецький національний університет, 2020. - T. 42. - C. 36-45

DOI: $10.31861 / \mathrm{mhpi} 2020.42 .36-45$

УДК 327(091):323.12(438):341.384
Modern Historical and Political Issues: Journal in Historical \& Political Sciences. - Chernivtsi: Chernivtsi National University, 2020. - Volume. 42. - pp. 36-45 DOI: $10.31861 / \mathrm{mhpi} 2020.42 .36-45$

(C) Орест Бойчук ${ }^{1}$

\title{
Проблема політики пам'яті у польсько-німецьких відносинах
}

Дослідження історичної політики неможливе без аналізу основних «історичних» проблем у польсько-німецьких відносинах. В контексті перемовин над Договором про кордони у 1990 р. на порядку денному двосторонніх відносин постала проблема політики пам'яті.

Питання відшкодування для польських жертв нацизму стала символічною проблемою, адже факт сплати відшкодування формував моральне задоволення серед польського населення.

Водночас проблема виплат відшкодування для польського населення формувала зв'язок 3 реституційними вимогами німецького населення за втрачене майно в ході переселенських кампаній. Це створило б додаткові проблеми в процесі ратифікації Договору про кордони. Такий контекст розуміли обидва уряди.

Німецька сторона в процесі вирішення виплат жертвам нацизму побоювалася фінансових втрат. I якщо в першій фазі вирішення питання цей підтекст не був настільки очевидний, адже i Польща потребувала додаткових грошових надходжень в процесі економічної трансформації, то вже в другій фазі, яка розпочалася від 1998 р. фінансові втрати були чітко викристалізувані для німецької економіки у випадку не вирішення проблеми.

Ключові слова: відшкодування, польські жертви нацизму, політика пам'яті, польськонімецькі відносини, польсько-німецьке порозуміння.

\section{The Problem of Memory Policy in Polish-German Relations}

The main idea of upon article is the pragmatic vision to an understanding of the "historical problems" role led to solving some challenges, which took place in the early stages of Polish-German understanding. But is needed to mark, the history had one of the leading roles in this process.

Of course, the negotiation on the signing of the German-Polish Border Treaty was hard. The legacy of the World War II influenced the process. The legacy was rooted in a few unsolved questions: the question of demands of expelled people to the Polish Government and the question of indemnity for Polish victims of Nazism.

For the new democratic Polish Government, the question of indemnity was "highly ranked". For many years, Polish society tried to take financial compensation for the crime of Nazism. But, due to ideological reasons, it can't reach it. On the other hand, the economy of Poland was in deep degradation, which had caused by transformation to the new market economy. And the Polish Government planned to take some advantages in the process of the negotiation.

Germans Chancellor H. Kohl had a strong linkage with the expelled environment. Due to this reason, the Head of the Western German Government had fear about the future of the Polish-German Border Treaty. He feared the worth - a voting failure for ratification of the Treaty. In this case, H. Kohl tried to avoid this question in the negotiation process.

During the negotiation, German understand clearly, it needs to avoid treatment compensation for Polish people as reparations for Poland. The roots of this reason located in the Moscow Treaty by 1953. According to the Moscow Treaty, Polish People Republic has abandoned from reparations demands on behalf of the German Democratic Republic. Moreover, Polish People Republic proclaimed on behalf of the whole German, including the Federal Republic of German.

$\mathrm{H}$. Kohl understands the significance of this decision and tried to support avoiding historical questions from the negotiation process.

But, the problems of indemnity for victims of Nazism were discovered with new power at the end

\footnotetext{
1 Асистент кафедри міжнародних відносин Прикарпатського національного університету імені Василя Стефаника, Україна. E-mail: orest.boichuk@pnu.edu.ua; https://orcid.org/0000-0002-0433-365X.
} 
of the 90th. During the international negotiation, Germany commonly with German business created Special Fund "Erinnerung, Verantwortung und Zukunft" for payment of compensation for a wide range of victims, including for Polish victims.

Keywords: indemnity, polish victims of Nazism, memory policy, Poland-German relations. Poland-German understanding.

Постановка наукової проблеми та ії значення. Проблема врегулювання виплати компенсації за примусову працю польському населенню стала однією з тих, яку не вдалося вирішити в період «холодної війни» між країнами. Виплати відшкодувань піддалися впливу ідеологічної боротьби на міжнародній арені та перебували в тіні поділу Німеччини.

3 однієї сторони, в Федеративні Республіці Німеччина (далі - ФРН) у 1956 р. був прийнятий Закон про відшкодування, який регламентував виплати відшкодування для цивільного населення за злочини нацистського режиму. Однак, з ідеологічних причин країни соцтабору не взяли участі у програмі виплат.

3 іншої сторони, на основі Договору в Москві від 1953 р. Польща зріклася будь-яких репараційних відшкодувань на користь Німецької Демократичної Німеччини (далі - НДР). Частково питання відшкодування вирішилося під час візиту В. Брандта у 1970 р. до Варшави у формі кредиту для польської економіки.

Проте, політичні еліти обох країн розуміли, що проблема і надалі не вирішена і заново постала в процесі перемовин над Договором про кордони між Польщею та ФРН у 1990 p.

Підсилилася проблема і іншим питанням - проблемою відшкодування для німецького населення за втрату майна в результаті переселення в 1944-1949 pр.

Згадані аргументи перебували в тіні історичної пропаганди радянського союзу в Польській Народній Республіці (далі - ПНР) та в контексті моральної відповідальності Німеччини за злочини проти польського населення.

Особливо актуальною тема постає в контексті намагань польського уряду під керівництвом парті «Право і Справедливість» повернути в польське суспільство дискусію щодо репарації зі сторони Німеччини на користь Польщі.

Аналіз останніх досліджень. Проблема виплати компенсацій для польського населення $\epsilon$ актуальною в польському науковому дискурсі. В. М. Гуральський аналізує проблему в контексті реституційних вимог німецького населення ${ }^{2}$. Теперішній керівник Фонду «Польськонімецьке поєднання» Я. Дека стверджує, що хоча сам факт виплат підтвердив історичну відповідальність Німеччини за злочини, однак сума виплат не покриває всіх втрат для польського населенняㄱ. Є. Кранц намагається дослідити правовий аспект фінансових виплат для польського населення в світлі як внутрішнього законодавства обох країн так і міжнародно правове врегулювання проблеми репарацій ${ }^{4}$. Безпосередній учасник перемовин над Договором про кордони Є. Сулек робить аналіз проблеми з економічної сторони 5

\footnotetext{
${ }^{2}$ Góralski, W. M., 2008. Polska-Niemcy: Trudny pproces pojednania (sprawy zamknięte - sprawy otwarte), in Rotfeld A. D., 2008. Dokąd zmierza świat? Warszawa: PISM. Pp. 405-430; Góralski, W. M., 2011. Niemiecki roszczenia restytucyjno-odszkodowawcze wobec Polski. ostateczne zamknięcie sporu w świetle prawa międzynarodowego, in Góralski, W. M., 2011. Przełom i wyzwanie. XX lat Polsko-Niemieckiego Traktatu o Dobrym Sąsiedztwie i Przyjaznej Współpracy 1991-2011. Warszawa: Elipsa. Pp. 521-585.

${ }^{3}$ Deka J., 2005. Niemieckie świadczenia dla robotników przymusowych i niewolniczych. Przegląd Zachodni. $\mathrm{Nr}$ 2. Pp. 138-154.

${ }^{4}$ Kranz, J., 2011. Polsko-niemieckie kontrowersje prawne - próba bilansu, in Góralski, W. M., 2011. Przełom i Wyzwanie. XX Lat Polsko-Niemieckiego Traktatu o Dobrym Sąsiedztwie i Przyjaznej Współpracy 1991-2011. Warszawa: Elipsa. Pp. 477-520.

${ }^{5}$ Sułek, J., 2004. Niemiecka Pomoc Humanitarna i Finansowa w Latach 1991-2004 Dla Poszkodowanych Przez III Rzesze w Polsce. Problemy Polityczne i Prawne, in Góralski, W. M., 2004. Problem Reparacji, Odszkodowań i Świadczeń w Stosunkach Polsko-Niemieckich 1944-2004. Warszawa: Polski Instytut Spraw Międzynarodowych. Pp. 337-376; Sułek, J., 2004. Świadczenia finansowe dla byłych robotników niewolniczych $i$ przymusowych III Rzeszy oraz innych ofiar Nazizmu. Bilans wyplat w Polsce z lat 1999-2004, in Góralski, W. M., 2004. and Dębski S., 2004. Problem reparacji, odszkodowań i świadczeń w stosunkach polsko-niemieckich 1944-2004. Studia. T. 2. Warszawa: Biuro analiz PISM. Pp. 379-424; Sułek, J., 2011. Od odszkodowań indywidualnych do pomocy humanitarnej i świadczeń finansowych. Bilans wypłat z Niemiec z lat 1991-2011 dla
} 
Мета та завдання дослідження. Мета полягає в дослідженні проблеми отримання відшкодування від Німеччини за наслідки Другої світової війни для польського населення в контексті історичної політики в двосторонніх відносинах. Для досягнення мети наукової розвідки необхідно вирішити наступні завдання:

- проаналізувати політико-правовий аспект проблеми відшкодування для польських громадян;

- дослідити фактичний стан виплат для польського населення;

- охарактеризувати вплив історичного наративу Польщі на процес вирішення проблеми виплат для німецького населення;

- виокремити підходи до вирішення проблеми виплат компенсації для польського населення.

Виклад основного матеріалу. Проблема відшкодування для примусових польських працівників в період нацизму побутувала у суспільній дискусії польського населення доволі довго. «Це питання намагався вирішити кожен уряд у Варшаві, але завжди він (варшавський уряд - прим. авт) натикався на опір зі сторони ФРН. [...] Всі розуміли, що хоч це питання стосувалося минулого, але без його позитивного вирішення, розмова про порозуміння буде передчасною» ${ }^{6}$ - зазначає М. Томала.

Сподівання на виплати компенсацій не лише примусовим працівникам, але жертвам націонал-соціалізму загалом в Польщі відновилися ще у 80-х рр. Це не випадково. Для цього існували як мінімум дві причини: демократичні переміни в самій Польщі та зміни історичної політики в Німеччині за ініціативи Г. Коля. Саме тоді в Німеччині розгорілася дебата про «забуті жертви» та відшкодування тим категоріям людей근 яких не охоплював Закон про відшкодування від 1956 р. (нім. Bendesentschädigungsgesetz) ${ }^{8}$. Закон встановлював термін складання заяви на відшкодування до 1969 р. ${ }^{9}$, а більшість населення соціалістичного табору з очевидних на те причин, не мали можливості скласти заяви.

Вже 20-23 січні 1989 р. тодішній прем’єр-міністр Ф. Раковський здійснив неофіційний візит до Бонн, де провів неофіційні перемовини з політичними лідерами ФРН. Заодно, на зустрічі В. Брандтом, а не з Г Колем, прем'єр порушив питання відшкодування для примусових робітників. В. Брандт відмовляв польського прем'єра від цього кроку та просив його не включати у порядок денний переговорів щодо Договору про нормалізацію кордону. Польський прем'єр планував отримати кошти для підтримки економіки Польщі, а для Німеччини це закрило б одне 3 питань у порядку денному польсько-німецьких відносин. Основними мотивами прохання В. Брандта не включати у двосторонні відносини питання про відшкодування стали велика сума відшкодування (біля 8 млрд. німецьких марок ${ }^{10}$ ) та бажанням не поєднувати минуле 3 нормалізацією у відносинах ${ }^{11}$.

Позиція польської сторони була слабкою, оскільки польський уряд через складну економічну ситуацію, був перед усім зацікавлений в отримані нових кредитів та фінансової допомоги на погашення попередніх кредитів ${ }^{12}$. Оцінюючи проблему відшкодувань 3 майбутньої перспективи, М. Томала звертає увагу на певний виграш на користь Німеччини процесі нормалізації проблеми виплат проблеми ${ }^{13}$, тим самим критикуючи здобутки польського уряду.

В негативну світлі розглядає позицію Варшави під час врегулювання питання відшкодування і Я. Дека, стверджуючи при цьому, що це питання «відносилося до найважливішої спірної

ofiar Nazizmu w Polsce, in Góralski, W. M., 2011. Przełom i wyzwanie. XX lat polsko-niemieckiego traktatu o dobrym sąsiedztwie i przyjaznej współpracy 1991-2011. Warszawa: Elipsa. Pp. 552-585

${ }^{6}$ Mieczysław T., 2004. Od porozumienia do wspótpracy: stosunki polsko-niemieckie w latach 1991-2001: Wybrane zagadnienia. Kilce: Dom Wydawn. Elipsa, p. 145.

${ }^{7}$ Deka, J., 2005. Op. cit., p. 145.

${ }^{8}$ Barcz, J., 1989. Projekty ustawodawcze w Bundestagu (1985 -1987) w sprawie odszkodowań dla ofiar prześladowań faszystowskich, Przegląd Zachodni. Nr. 1. p. 127.

${ }_{9}^{9}$ Bundesgesetz zur Entschädigung für Opfer der Nationalsozialistischen Verfolgung Bundesentschädigungsgesetz - BEG. Available at: https://www.gesetze-im-internet.de/beg/BEG.pdf. [accessed Aug. 21, 2020].

${ }^{10}$ Така побутувала на той час сума завданих збитків для Польщі.

${ }^{11}$ Sułek, J., 2011. Op. cit., p. 561.

${ }^{12}$ Mieczysław, T., 2004. Op. cit., p. 145.

${ }^{13}$ Ibidem. 
проблеми між демократичною Польщею та об'єднаною Німеччиною» ${ }^{14}$.

Є. Сулек, представник Польщі на переговорах щодо підготовки договору між обома країнами зазначає: «3 огляду на морально-політичний вимір, індивідуальні відшкодування для польських громадян належали до «високого рангу» проблем, які необхідно вирішити між ПНР та $Ф Р Н{ }^{15}$. В процесі перемовин над текстом Договору про кордони, проблематика відшкодувань була відсунута на другий план в світлі проблеми врегулювання питання кордону між обома країнами. Водночас «уряду Т. Мазовецького вдалося показати цю проблему як одну з найважливіших» ${ }^{16}$.

«Польський уряд декларував свою підтримку прагнень польських громадян про відшкодування за втрати понесені під час Другої світової війни. Однак, федеральний уряд, хоч і відчуваючи вину за «криваве минуле», вважав питання репарацій чи відшкодувань закритим ще у 50 -х рр.» ${ }^{17}$ - зазначає Я. Дека, звертаючи увагу на те, що в кінцевому результаті це призвело до «аукціону жертв» ${ }^{18}$, або отримання додаткових важелів впливу на Польщу взамін вирішення проблеми з виплатою відшкодування.

Рефлексуючи в позитивному світлі на тему вирішення проблеми, безпосередній учасник польсько-німецьких переговорів С. Сулек зазначає, що «проблема відшкодування за примусову працю була згадана в Спільній Заяві від 1989 р., та в Преамбулах двох договорів: Договору про кордони від 14 листопада 1990 р. та Договору про добросусідство від 17 червня 1991 р.»19.

Водночас на практиці виглядало доволі все натягнуто, так як в обох договорах ${ }^{20}$ цієї проблеми не було закріплено, а в Спільній Заяві лише опосередковано згадано «врегулювання історичних проблем між обома країнами» ${ }^{21}$.

М. Столярчик зазначає, що «питання відшкодування шкоди для громадян Польщі за примусову працю в період Другої світової війни та претензії німецьких громадян 3 приводу втрати власного майна в результаті депортації в 1945-1949 рр. не розглядалися в Договорі про кордони та Договорі про добросусідські відносини. Причиною цьому слугувало розуміння серед політичних еліт обох країн того факту, що не вдасться досягнути компромісу в даному питання $\rangle^{22}$. Д. Блуменвіц поєднує питання відшкодування для німців разом з вирішенням питанням правового статусу німецької меншини в Польщі ${ }^{23}$, де Польща отримує гроші, а взамін надає більше повноважень для німецької меншини та юридично визначає їх статус.

Ініціатором виключення питання відшкодування за примусову працю до Договору про врегулювання кордону стала саме Польща ${ }^{24}$. Є. Сулек зазначає, що для такої ініціативи існували щонайменше дві причини: глибока розбіжність правових позицій між сторонами та принцип взаємності ${ }^{25}$.

Німецька сторона доволі раціонально підійшла до питання виплати відшкодувань. 3 самого початку офіційний Бон не хотів допустити того, щоб у Договорі про кордон було вміщено згадку про відшкодування, а тим більше щоб цей договір мав назву «peace settlement» ${ }^{26}$. Фактично

${ }^{14}$ Deka, J., 2005. Op. cit., p.145.

${ }^{15}$ Sułek, J., 2011. Op. cit., p. 552.

${ }^{16}$ Ibidem.

${ }^{17}$ Deka J., 2005. Op. cit., p. 145.

${ }^{18}$ Ibidem.

${ }^{19}$ Sułek, J., 2011. Op. cit., pp. 552-553.

${ }^{20}$ Traktat między Rzecząpospolitą Polską a Republiką Federalną Niemiec o dobrym sąsiedztwie i przyjaznej współpracy, podpisany w Bonn dnia 17 czerwca 1991 r. Available at: http://isap.sejm.gov.pl/isap.nsf/ DocDetails.xsp?id=WDU19920140056 [accessed 3 August 2020]; Traktat między Rzecząpospolitą Polską a Republiką Federalną Niemiec o potwierdzeniu istniejącej między nimi granicy, podpisany w Warszawie dnia 14 listopada 1990 r. Available at: http://isap.sejm.gov.pl/isap.nsf/DocDetails.xsp?id=WDU19920140054 [accessed 3 August 2020].

${ }^{21}$ Góralski, W. M., 2011. Op. cit., pp. 521-585.

${ }^{22}$ Stolarczyk, M., 2010. Zbieżność i różnice interesów w stosunkach polsko-niemieckich w latach 1989-2009. Katowice: Wydawnictwo Uniwersytetu Śląskiego, p. 111.

${ }^{23}$ Wiliński, M., 2007. Stosunki polsko-niemieckie w latach 1982-1991. Katowice: Wydawnictwo Naukowe 'Śląsk', p. 171.

${ }^{24}$ Sułek, J., 2011. Op. cit., p. 554.

${ }^{25}$ Ibidem, p. 553.

${ }^{26}$ Kranz, J., 2011. Op. cit., p. 498. 
федеральний уряд не хотів, щоб історичні проблеми мали фінансові наслідки. Тому так легко він погодився на без договірному врегулюванні питання.

Трактування правових підстав до виплат компенсації польським громадянам зі сторони федерального уряду базувалося на Договорі в Москві від 1953 р. за яким Польща відмовилася від будь-яких репарацій на користь НДР. Однак, офіційна Варшава доволі часто дискутувала над правовим статусом цього договору.

Визнання Договору про кордони як Договору про мирне врегулювання приніс би дві проблеми: ануляцію Договору в Москві від 1953 р. та відкриття нової дискусії про репараційні вимоги. Складнішим виглядає принцип взаємності. Адже за словами Є. Сулека це могло призвести до зростання вимог зі сторони німецького населення про відшкодування за втрату майна на колишніх східних територіях в результаті переселення. Також, для польської сторони вирівнювання втрат призвело б до нівелювання дихотомії «жертва-злочинець» ${ }^{27}$. Фактично це б призвело до того, що німецькі громадяни забезпечили собі право на відшкодування за втрачене майно, а польська історична політика визнала себе як «злочинець», який здійснив переселення порушуючи основоположні права людини. Це аж ніяк не входило до доктрини історичної політики Польщі, яка на той час формувалася піл впливом радянської пропаганди.

Тому Т. Мазовецький обрав недоговірний шлях вирішення питання про відшкодування для польських громадян ${ }^{28}$. Концепція вирішення питання недоговірним шляхом давала Польщі додаткові можливості. Адже, якщо для підписання договору необхідно погодження обох сторін, а в подальшому ратифікація через законодавчі органи, то недоговірний шлях, на основі обміну листів, забезпечував вирішення питання на основі прийняття пропозиції партнера. Іншими словами вирішувалося питання лише відшкодувань на користь Польщі зі сторони Німеччини ${ }^{29}$, тим самим не зачіпалося питання відшкодувань для німецьких громадян, яке би напевно постало під час Ратифікації в Бундестазі.

Німецький уряд, грунтуючись на Договорі в Москві від 1953 р., згідно з яким від 1 січня 1954 р. Польща відмовляється на користь Німеччини (цілої Німеччини sic!, а не НДР, 3 якою був підписаний договір), розумів небезпеку індивідуальних позовів, адже вони могли перетворитися на репараційні вимоги ${ }^{30}$. Німеччина прагнула підтвердити правову основу відмови польською стороною від репарацій на свою користь.

$€$ Кранц, зазначає, що польський уряд розумів свою слабку позицію через зволікання 3 виплатами відшкодувань. Вже пройшло багато часу від завершення війни, а чим дальше, тим важче буде домогтися відшкодувань ${ }^{31}$. 3 іншої сторони, польські громадяни, та й загалом країни соціалістичного табору були майже виключені з процесів відшкодувань, які проводив уряд ФРН у 50-60-х рр. ХХ ст. ${ }^{32}$. Через це обидві сторони погодилися прийняти формулу «не відшкодування, а гуманітарна допомога».

Варто звернути увагу на той факт, що ПНР та її громадяни отримали вже гуманітарну допомогу (знову ж таки гуманітарні виплати) за псевдонаукові експерименти від ФРН у 1972 р. у сумі 140 (+3 млн. марок на адміністративні витрати $)^{33}$. Але на той час гуманітарна допомога стала частиною маніпуляцій уряду ПНР, підкреслюючи наратив відкупу від заподіяних Третім Рейхом злочинів ${ }^{34}$, а кошти не завжди розподілялися для громадян.

Польські автори стверджують, що виплата відшкодувань несла більше символічний характер $^{35}$. Іншими словами підтвердження та аргументація серед польського населення історичного злочину, який здійснила Німеччина проти Польщі та їі громадян.

Польща відстоювала збереження історичної справедливості та наполягала на важливості вирішення «історичного питання» задля польсько-німецького порозуміння. В ході переговорів над Договором про кордони, представником Польщі Є. Сулеком було наголошено, що «процес

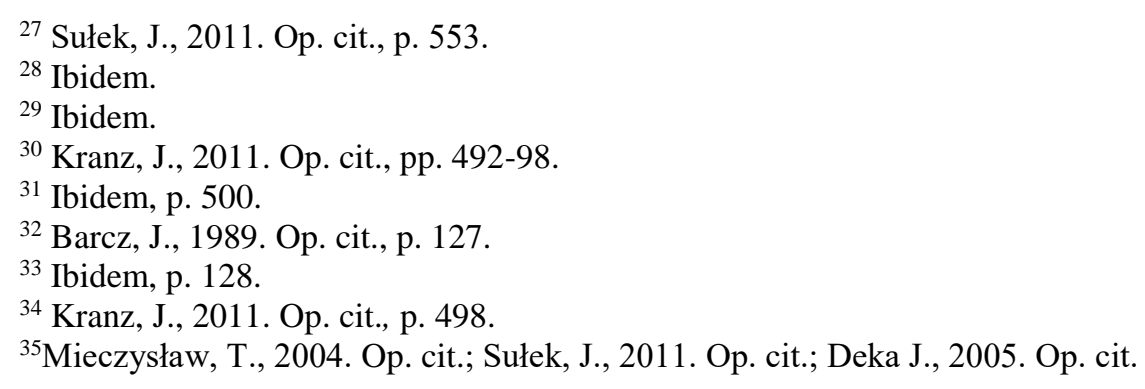


розрахунку з минулим не може бути досягнутий в польсько-німецьких відносинах без вирішення проблеми відшкодування і все залишиться постарому, навіть після підписання договорів. Польське суспільство просто не дозволить цього уникнути, особливо в зв'язку з тим, що у 80-х pp. зросли очікування серед громадян Польщі про відшкодування за нацистські переслідуванНя) ${ }^{36}$.

На фоні зміни підходів до історичної політики канцлером Г. Колем, «Зелені» та СДП ініціювали дискусію про повернення відповідальності за злочини Другої світової війни нацистським режимом ${ }^{37}$. Обидві парті підтримали попередню домовленість обох урядів про формування Фонду «Польсько-німецьке поєднання», який був представленим Г. Колем на засіданні Бундестагу 6 вересня 1991 р. Варто звернути увагу, що Г. Коль, щоб якимсь чином зменшити критичні настрої серед ХДС-ХСС зазначив, що «виплати отримають лише ті люди, які зазнали особливо тяжких втрат» ${ }^{38}$.

Вже в жовтні 1991 р. було підписано порозуміння між Німеччиною та Польщею про створення Фонду «Польсько-німецьке поєднання». Одразу після створення Фонду, 16 жовтня відбувся обмін листами між К. Жаблінським та Д. Каструпом, в рамках якого було погоджено вирішення проблеми відшкодування за примусову працю поляків та іншим жертвам ${ }^{39}$. Власне дипломатичне листування стало юридичною формою закріплення виплат.

У листі Д. Каструп до К. Жаблінського написав, що «Уряд Федеральної Республіки Німеччина $[\ldots]$ готовий внести 500 млн. марок ${ }^{40}$ на рахунок Фонду «Польсько-Німецьке поєднання». [...] Фонд також може отримувати кошти також від фізичних і юридичних. [...]. Кошти 3 рахунків Фонду будуть виплачуватися виключно для осіб, які найбільше постраждали від нацистського переслідування [...], а серед критеріїв будуть наступні: серйозна втрата здоров'я та складна матеріальна ситуація» ${ }^{41}$.

У відповідь К. Жаблінський написав: «Уряд РП не буде висувати подальших вимог про відшкодування, які могли б виникати у зв'язку з нацистськими переслідуваннями» ${ }^{42}$.

В результаті угоди «Жаблінський-Каструп» розпочалося вирішення однієї зі складних проблем минулого в польсько-німецьких відносинах. Згадана формула мала кілька важливих наслідків. Врешті решт вдалося символічно вирішити проблеми відшкодування за нацистські переслідування польського населення. Чимало польських науковців звертають увагу на той факт, що хоч і ці відшкодування не покривали всі страждання, але несли в собі моральний чинник «вибачення» за німецькі злочини та показували моральну перевагу Польщі в Другій світовій війні.

Незважаючи на те, що в листі Д. Каструпа доволі загально окреслено постраждалих, все ж було сформовано категорію осіб, яким передбачалося відшкодування. Більш детальне виокремлення категорії осіб, які можуть претендувати на відшкодування належало до привілеїв польської сторони. В результаті діяльності Експертної Комісії було сформовано кілька категорії. Найбільш значними стали наступні ${ }^{43}$ :

- особи як перебували в концентраційних таборах, гетто;

- особи, які перебували в таборах «Polenlager»в Сілезії;

- змушені до примусових робіт на термін більше ніж 6 місяців та які покинули, місця свого проживання;

- дітям, які народилися і перебували в різного роду таборах;

- дітям, які зазнали «онімечення».

Шляхом листування напевно один з найбільш важливіших питань, яке було зняте з порядку денного двосторонніх відносин, та заспокоювало певні суспільно-політичні кола в Німеччині це відмова від дипломатичної підтримки польським урядом своїх громадян в тому випадку

\footnotetext{
${ }^{36}$ Sułek, J., 2011. Op. cit., p. 555.

${ }^{37}$ Mieczysław, T., 2004. Op. cit., p. 146.

${ }^{38}$ Ibidem.

${ }^{39}$ Ibidem.

${ }^{40}$ В перерахунку на польські злоті, сума переказу становила 417,3 млн. злотих.

${ }^{41}$ Цит. за: Tomala, М., 2004. Od porozumienia do wspótpracy: stosunki polsko-niemieckie w latach 1991-2001:

Wybrane zagadnienia, pp. 146-47.

42 Ibidem, p. 148.

${ }^{43}$ Wypłaty świadczeń. Available at: fpnp.pl/Wypłaty-świadczeń.html [accessed 4 August 2020].
} 
індивідуальних позовів. Про це між іншим зазначив К. Жаблінські у своєму листі-відповіді до Д. Каструпа. На це наголошують Є. Сулек ${ }^{44}$ та $Є$. Кранц ${ }^{45}$.

I останній за рахунком та не за важливістю наслідок: Німеччині в результаті перемовин вдалося уникнути використання терміну «репарація» в процесі відшкодувань. Як і в статуті організації так і в результаті листування «Каструп-Жаблінські» було використано термін «гуманітарна допомога за переслідування нацистами» або допомога ex gratia. Це дало змогу забезпечити і надалі юридичну обов'язковість Договору у Москві від 1953 р., який регламентував скасування виплат репарацій.

Німеччина зобов'язалася направити 500 млн. марок на рахунок Фонду Польсько-німецьке поєднання ${ }^{46}$. Як подає Є. Сулек, в період 1992-2004 pр. з Фонду отримали 731,8 млн. злотих ${ }^{47}$ більше ніж мільйон осіб ${ }^{48}$.

Цікавим виглядає наратив побудови інформації про виплати від Німеччини на сайті Фонду «Польсько-німецьке порозуміння». Перш за все згадано те, що Польща як і інші країни Центрально-Східної Європи не отримали допомоги за примусову роботу в рамках Закону про відшкодування від 1954 p. ${ }^{49}$, при цьому наголошується саме на відшкодуванні ${ }^{50}$ (sic!). 3 іншої сторони зазначається, що «гуманітарна допомога» (sic!) не є цілісним відшкодуванням, а лише символічною гуманітарною допомогою. Фактично Польща не визнає виплати для польського населення як репарацію чи відшкодування, а лише як «гуманітарну допомогу».

3 новою силою проблема виплат для примусових польських працівників постала на початку діяльності Г. Шрьодера ${ }^{51}$ і причиною для цього стали не лише прагнення польського населення. Важливу роль відіграв міжнародний аспект справи. Активізація діяльності німецького уряду у фінансуванні виплат для примусових робітників була спричинена позовами громадян Польщі, Ізраїлю та США до приватних німецьких компаній, які використовували примусову працю.

В кінці 1998 р. в США кілька громадян з метою відшкодування подали до суду на дві німецькі компанії «Volkswagen» та «Siemens», звинувачуючи їх у використанні примусової праці в період II Світової війни ${ }^{52}$. В листопаді того ж року був поданий колективний позов проти двох німецьких банків «Deutsche Bank» та «Dresdner Bank» 3 подібними звинуваченнями ${ }^{53}$.

Саме тоді кілька найбільших фірм, які в період Другої світової війни використовували примусову працю в'язнів концентраційних таборів, побоюючись багатомільйонних відшкодувань, виступили з ініціативою створення фонду, який би виплачував відшкодування ${ }^{54}$. В результаті сформованої після виборів коаліції СДП-Союз90/Зелені до коаліційної угоди внесено питання про формування спеціального фонду, модель якого запропонували німецькі фірми ${ }^{55}$. Уряд розуміючи економічні та політичні наслідки незакритої проблеми відшкодування, яка спричинена Другою світовою війною, вже 16 лютого разом 312 фірмами представили проєкт фонду ${ }^{56}$.

Зі сторони Польщі достатньо часто питання виплат поставало на порядку денному суспільних дискусій. В бік Німеччини лунали закиди про те, що виплати, котрі здійснювалися на основі домовленості «Каструп-Жаблінський» та виплачувалися 3 Фонду польсько-німецького

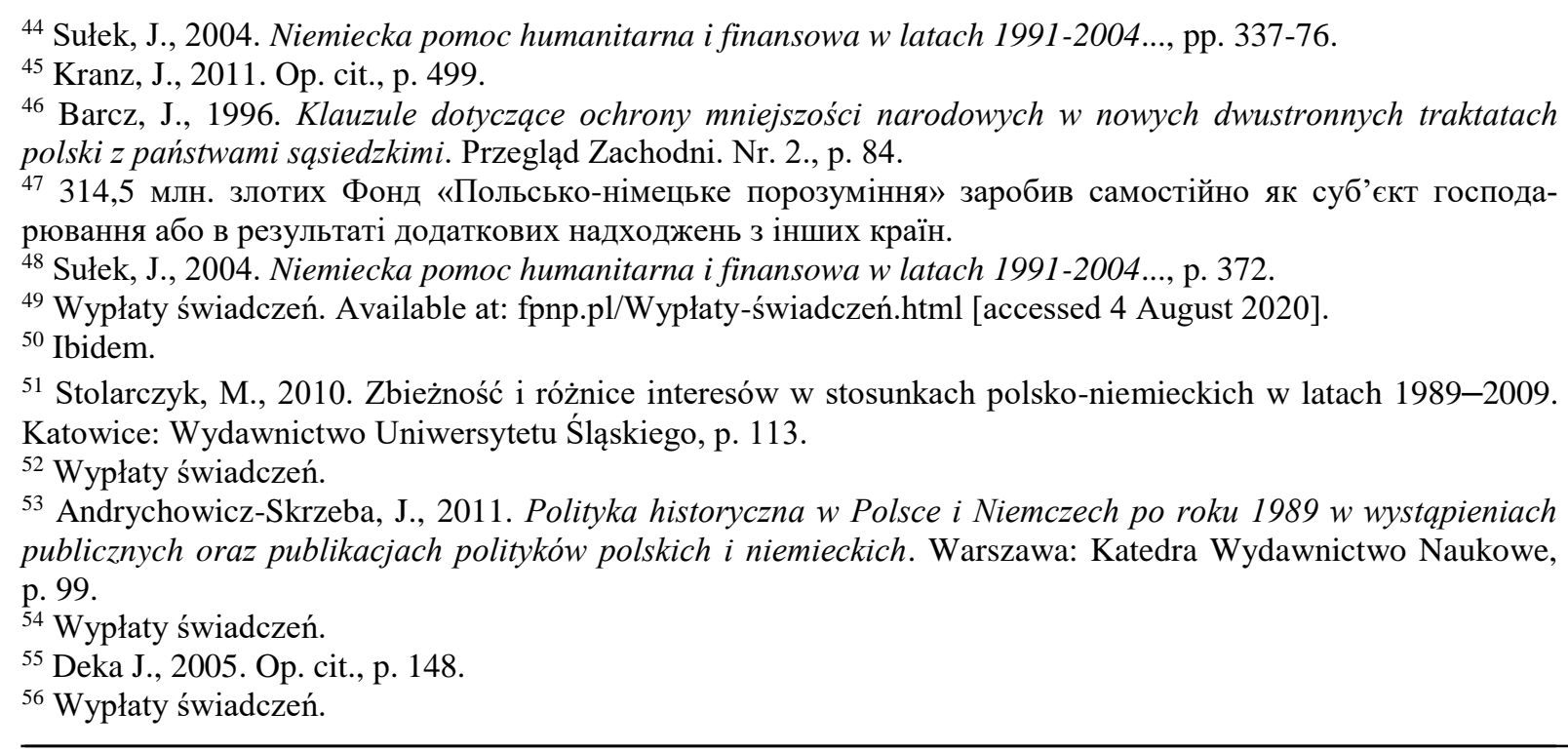


поєднання були малими ${ }^{57}$. Окрім виплат примусовим працівникам, інші категорії постраждалих не отримали очікуваного відшкодування ${ }^{58}$. Тому польський уряд активно долучився до переговорів $з$ щодо нової формули відшкодування. Варто звернути і на той факт, що від 1998 р. зростають вимоги переселених німців про відшкодування. Однак через міжнародний контекст перемовин, питання реституційних вимог залишилося поза увагою.

В результаті багатосторонніх перемовин вирішено створити Фонд «Пам'ять, відповідальність майбутнє». Спільна заява учасників переговорів про формування Фонду була підписана в Берліні, 17 липня 2000 р., а Закон про створення Федерального фонду прийнятий 2 серпня 2000 р. Бюджет Фонду складався з 10,1 млрд. марок або 5,2 млрд. євро ${ }^{59}$.

Фінансування програми відбувалося наступним чином: половина коштів з федерального бюджету та половина коштів від доходу з німецької промисловості. Як зазначає Є. Сулек, Польща в рамках переговорів наголошувала на сумі в 4,8 млрд. марок для своїх громадян ${ }^{60}$, однак не отримала бажаної суми. Перші виплати були запланована на 60-ту річницю початку II Світової війни. Для багатьох поляків рішення про створення фонду привнесло позитивний аспект та стало прикладом німецької щирості на фоні загострення суперечок з Союзом Вигнаних ${ }^{61}$.

Бенефеціаром виплат для польських громадян став Фонд «Польсько-німецьке поєднання». Між Фондом польсько-німецького порозуміння та Фондом «Пам'ять, відповідальність і майбутнє у вересні підписано угоду, в якій сторони домовилися співпрацювати в справі виплат відшкодування ${ }^{62}$. Для поляків в рамках угоди було виділено 1,812 млрд. марок ${ }^{63}$, що становило $22,3 \%$ від загальної суми Фонду «Пам'ять, відповідальність, майбутнє» (далі Фонд Пам’ять) ${ }^{64}$.

Згідно з оцінками Фонду Пам'ять, Польща посіла перше місце серед кількості осіб, які отримали відшкодування та друге місце за сумою виплат ${ }^{65}$. У вересні 2006 програма виплат примусовим працівника була завершена ${ }^{66}$. Для польських громадян було виплаченою 900 млн. дол. США ${ }^{67}$.

«Назва фонду (Фонд «Пам’ять» - прим. авт.) не була випадковою. Кожне слово було символом» ${ }^{68}$ - рефлексує М. Томала про успіхи польської дипломатії у багатосторонніх переговорах. «Пам'ять означала пам'ять про варварство і Аушвіц. Відповідальність означала те, що німці зобов'язані боротися проти варварства. Пам'ять означала, що лише суспільство, яке усвідомлює своє минуле, може будувати гарне майбутнє» ${ }^{69}$.

Керівник польської делегації на переговорах, Є. Кранц у своєму виступі з нагоди підписання угоди про відшкодування, 17 липня 2000 в Берліні зазначив: «Польський уряд виражає своє задоволення тому, що незважаючи на більше як 50-ти літній період після завершення Другої світової війни та політичні обставини, дійшло до рішення, в результаті якого, жертви націоналсоціалізму - колишні примусові робітники та в'язні - отримали фінансові виплати віл німець-

\footnotetext{
${ }^{57}$ Czech, M., 2000. Stosunki z Niemcami. Rocznik Polskiej Polityki Zagranicznej, Nr.1, p. 118.

${ }^{58}$ Ibidem, pp. 112-20.

${ }^{59}$ Zahlen und Fakten. Stiftung "Erinnerung, Verantwortung und Zukunft". Available at: https://www.stiftungevz.de/stiftung/zahlen-und-fakten.html [accessed 5 August 2020].

${ }^{60}$ Sułek, J., 2004. Świadczenia finansowe dla byłych robotników niewolniczych i przymusowych..., pp. 385-386.

${ }^{61}$ Ibidem, p. 379.

${ }^{62}$ Zahlen und Fakten. Stiftung "Erinnerung, Verantwortung und Zukunft.

63 3,5 млрд. євро. Варто звернути на той факт, що в процесі виплат виникли невдоволення серед польських громадян, так у зв'язку з переходом на євро, курс доволі часто коливався. В результаті були призначені додаткові компенсаційні виплати у зв'язку з курсовою різницею.

${ }^{64}$ Deka J., 2005. Op. cit., pp. 151-52.

${ }^{65}$ Wypłaty Świadczeń.

${ }^{66}$ Sprawiedliwe odszkodowanie nigdy nie będzie możliwe. 30.04.2010, DW.COM Available at: https://www.dw. com/pl/sprawiedliwe-odszkodowanie-nigdy-nie-b\%C4\%99dzie-mo\%C5\%BCliwe/a-5521508> [accessed 10 January 2020].

${ }^{67}$ Fischer, T., 2015. Zwangsarbeiter-Enschädigung. in Lorenz M.N., 2015. Lexikon Der 'Vergangenheitsbewältigung' in Deutschland. Debatten- Und Diskursgeschichte Des Nationalsozialismus Nach 1945. Bielefeld: Transcript, p. 324.

68 Tomala, M., 2004. Od porozumienia do wspótpracy: stosunki polsko-niemieckie w latach 1991-2001: Wybrane zagadnienia, p. 151.

${ }^{69}$ Ibidem, p. 151.
} 
кого федерального Фонду «Пам’ять, Відповідальність, Майбутнє»»» ${ }^{70}$.

Я. Дека не так однозначно та позитивно оцінює вирішення питання. Незважаючи на те що, німецькі фірми декларували свою відповідальність перед історією та історичним минулим, причиною ж швидкого рішення про формування спеціального фонду стали економічні мотиви. Адже, колективні позови до німецьких фірми в США чи країнах Свропи могли призвести до багатомільйонних втрат для німецьких компаній ${ }^{71}$.

В першій половині 90-х рр. вдалося досягнути чималих успіхів в польсько-німецьких відносинах. Серед них чільне місце посідає питання відшкодування. Важливу роль для цього зіграли постулати «концепції спільноти інтересів», яку впровадили до польсько-німецького дискурсу «батьки процесу та однозначно реалізатори створеної ними філософії польсько-німецького поєднання - церкви, політики, науковці, а також неурядові та урядові організації» ${ }^{72}$. Основою концепції стала деісторизація двосторонніх відносин та «християнські цінності без політичного підтексту» ${ }^{73}$, засновані на відомому листуванні між польськими та німецькими єпископатами.

Висновки. Завдяки прагматизму та розумінню ролі двосторонніх відносин для обох країн вдалося подолати історичну ненависть та закрити одну з складних та важливих проблем історії. Вочевидь існують і досі суперечки про результати домовленостей. Однак, попри все це, Польщі вдалося зберегти символічний статус жертви у Другій світовій війні, а Німеччину представити як злочинця, який повинен відповідати за свої злочини.

Виплата відшкодування для польського населення мала два етапи. Перший відбувався у двосторонньому контексті, а другий від 2004 р. був спричинений міжнародним контекстом, в рамках якого Німеччина могла зазнати значних економічних втрат в результаті позовів в інших країнах. Врегулювання проблеми виплат для польського населення мало важливі наслідки:

- Німеччині вдалося частко підтвердити юридичну важливість Договору в Москві від 1953 р. про відмову від репарацій на свою користь;

- німецька сторона на офіційному рівні отримала відмову від дипломатичної підтримки польською стороною свого населення в їх намаганнях отримання відшкодувань перед німецьким урядом;

- польська сторона перебуваючи в незручному становищі через те, що в плані термінів це питання стало нерелевантним для Німеччини, змогла частково отримати фінансове відшкодування для постраждалих;

- Варшава, яка мала кредитні зобов'язання та складне економічне становище, отримала реструктуризацію кредитів отриманих в 1972 р.;

- $\quad$ в процесі перемовин Польщі вдалося не поєднати реституційні вимоги німецького населення до польського уряду з питанням відшкодування для польського населення.

Таким чином, врегулюючи проблему виплат для польського населення виграш отримали $\mathrm{i}$ польська, і німецька сторони.

\section{References}

1. Andrychowicz-Skrzeba, J., 2011. Polityka historyczna w Polsce i Niemczech po roku 1989 w wystapieniach publicznych oraz publikacjach polityków polskich i niemieckich. Warszawa: Katedra Wydawnictwo Naukowe.

2. Barcz, J., 1989. Projekty ustawodawcze w Bundestagu (1985 -1987) w sprawie odszkodowań dla ofiar prześladowań faszystowskich. Przegląd Zachodni. Nr. 1. Pp. 127-128.

3. Barcz, J., 1996. Klauzule dotyczace ochrony mniejszości narodowych $w$ nowych dwustronnych traktatach Polski z państwami sąsiedzkimi. Przegląd Zachodni, Nr. 2. Pp. 61-87.

4. Bundesgesetz zur Entschädigung für Opfer der Nationalsozialistischen Verfolgung Bundesentschädigungsgesetz - BEG. Available at: https://www.gesetze-im-internet.de/beg/BEG.pdf. [accessed Aug. 21, 2020].

5. Czech, M., 2000. Stosunki z Niemcami. Rocznik Polskiej Polityki Zagranicznej. Nr. 1. Pp. 109-127.

\footnotetext{
70 Tomala, M., 2004. Op. cit., p. 152.

${ }^{71}$ Deka J., 2005. Op. cit., p. 149.

${ }^{72}$ Góralski, W. M., 2008. Op. cit., p. 415.

${ }^{73}$ Ibidem, p. 415.
} 
6. Deka, J., 2005. Niemieckie świadczenia dla robotników przymusowych i niewolniczych. Przegląd Zachodni. Nr 2. Pp. 138-154.

7. Fischer, T., 2015. Zwangsarbeiter-Entschädigung, in Lorentz N.M., 2015. Lexikon Der 'Vergangenheitsbewältigung' in Deutschland. Debatten- Und Diskursgeschichte des Nationalsozialismus nach 1945. Bielefeld: Transcript. Pp. 337-339.

8. Góralski, W. M., 2008. Polska-Niemcy: trudny proces pojednania (sprawy zamknięte sprawy otwarte), in Rotfeld A. D., 2008. Dokąd zmierza świat? Warszawa: PISM. Pp. 405-430.

9. Góralski, W. M., 2011. Niemiecki roszczenia restytucyjno-odszkodowawcze wobec Polski. Ostateczne zamknięcie sporu w świetle prawa międzynarodowego, in Góralski W. M., 2011. Przełom i wyzwanie. XX lat Polsko-Niemieckiego Traktatu o Dobrym Sąsiedztwie i Przyjaznej Współpracy 1991-2011. Warszawa: Elipsa. Pp. 521-585.

10. Kranz, J., 2011. Polsko-niemieckie kontrowersje prawne - próba bilansu, in Góralski W. M., 2011. Przełom i wyzwanie. XX lat Polsko-Niemieckiego Traktatu o Dobrym Sąsiedztwie i Przyjaznej Współpracy 1991-2011. Warszawa: Elipsa. Pp. 477-520.

11. Mieczysław, T., 2004. Od porozumienia do wspótpracy: stosunki polsko-niemieckie w latach 1991-2001: Wybrane zagadnienia. Kilce: Dom Wydawn. Elipsa.

12. Sprawiedliwe odszkodowanie nigdy nie będzie możliwe. 30.04.2010', DW.COM. Available at: https://www.dw.com/pl/sprawiedliwe-odszkodowanie-nigdy-nie-b\%C4\%99dzie-mo\%C5\%BCliwe/ a-5521508 [accessed: 10 August 2020].

13. Stolarczyk, M., 2010. Zbieżność i różnice interesów $w$ stosunkach polsko-niemieckich $w$ latach 1989-2009. Katowice: Wydawnictwo Uniwersytetu Śląskiego.

14. Sułek, J., 2004. Niemiecka pomoc humanitarna i finansowa $w$ latach 1991-2004 dla poszkodowanych przez III Rzeszę w Polsce. problemy polityczne i prawne, in Góralski, W. M., 2004. Problem reparacji, odszkodowań i świadczeń w stosunkach polsko-niemieckich 1944-2004. Warszawa: Polski Instytut Spraw Międzynarodowych. Pp. 337-376.

15. Sułek, J., 2004. Świadczenia finansowe dla bytych robotników niewolniczych $i$ przymusowych III Rzeszy oraz innych ofiar Nazizmu. Bilans wyptat w Polsce z lat 1999-2004, in Góralski W. M., 2004. and Dębski S., 2004. Problem reparacji, odszkodowań i świadczeń w stosunkach polsko-niemieckich 1944-2004. Studia. T. 2. Warszawa: Biuro analiz PISM. Pp. 379-424.

16. Sułek, J., 2011 Od odszkodowań indywidualnych do pomocy humanitarnej $i$ świadczeń finansowych. Bilans wyplat z Niemiec z lat 1991-2011 dla ofiar nazizmu w Polsce, in Góralski W. M., 2011. Przełom i wyzwanie. XX lat Polsko-Niemieckiego Traktatu o dobrym sąsiedztwie i przyjaznej współpracy 1991-2011. Warszawa: Elipsa. Pp. 552-585.

17. Tomala, M., 2004. od porozumienia do wspótpracy: stosunki polsko-niemieckie $w$ latach 1991-2001: wybrane zagadnienia. Kilce: Dom Wydawn. Elipsa.

18. Traktat między Rzecząpospolitą Polską a Republiką Federalną Niemiec o potwierdzeniu istniejącej między nimi granicy, podpisany w warszawie dnia 14 listopada 1990 r. Available at: http://isap.sejm.gov.pl/isap.nsf/DocDetails.xsp?id=WDU19920140054 [accessed: 3 August 2020].

19. Traktat między Rzecząpospolitą Polską a Republiką Federalną Niemiec o dobrym sąsiedztwie i przyjaznej współpracy, podpisany w Bonn dnia 17 czerwca 1991 r. Available at: http://isap.sejm.gov.pl/isap.nsf/DocDetails.xsp?id=WDU19920140056 [accessed 3 August 2020].

20. Wiliński, M., 2007. Stosunki polsko-niemieckie $w$ latach 1982-1991. Katowice: Wydawnictwo Naukowe 'Śląsk'.

21. Wypłaty świadczeń. URL: fpnp.pl/Wypłaty-świadczeń.html [accessed 4 August 2020].

22. Zahlen und Fakten. Stiftung "Erinnerung, Verantwortung Und Zukunft" Available at: https://www.stiftung-evz.de/stiftung/zahlen-und-fakten.html [accessed 5 August 2020]. 